\title{
Kamasan Puppet Painting, Balinese Traditional Comics
}

\author{
I Dewa Alit Dwija Putra ${ }^{1}$ \\ ${ }^{1}$ Desain Komunikasi Visual, Fakultas Industri Kreatif, Bandung, Indonesia \\ dwijaputra772@gmail.com (dwija putra)
}

\begin{abstract}
The development of comics in Indonesia at this time so rapidly besides the interest and public interest especially among children and teenagers so big. The tendency of comic visuals in Indonesia is dominated by Japan and America. Many of them have not yet learned that comics in Indonesia have been started since the past as the tradition of making reliefs on temples, wayang beber paintings as well as in ancient texts such as the tradition of writing on palm leaves. The creation of tradition comics in Bali can be seen in works of art such as kamasan puppet paintings and manuskrif lontar prasi. Kamasan puppets paintings is a visual-speaking media of his era, which raises stories related to the philosophy and teachings of the Balinese view of life. As a medium of information the form of this tradition works to have common elements and aspects of modern comics. This research is to know the elements of traditional comic formation as media of information in its era. And the shift of symbol values in the form of the work of the tradition. This study uses qualitative methods and visual analysis with data collection and information techniques using observations, interviews both structured and unstructured and observe traditional objects. Then to confirm the field data is done by literature study either book or via the internet. As a form of artwork, the tradition of a great ancestral heritage needs to be preserved the values and local wisdom it has.
\end{abstract}

Keywords kamasan, puppet, comic

\section{Introduction}

The development of comics in Indonesian is now so rapidly, various forms and types of comics emerged as well as the theme and media delivery either printed or electronic. Visually it is dominated by the influence of Japanese comics especially "Manga" and later Western visuals such as Marvel and Disney comics. Comics as a medium of information is so popular today by children, adolescents, and even adults because comics can be very entertaining and bring the reader as though involved and dissolve in the story he reads.

Comic also as an educative media, which can provide insight and knowledge. The power of comics as a medium of information lies in the images used to be combined with the text as an additional explanation in addition to the story built. Starting from the type of fiction, animal, factual, and history. There are also comics that reveal biographies and funny events. Viewed from the type and form of the comic itself is also diverse there are so-called comic strips, cartoon comics, comic books, advertizing comics and many more types. The emergence of various forms so because the comic is very flexible to be made with the target audience.

Increasing the interest or interest of children, teenagers, and young people, to comics today, they often forget that the comic has existed since ancient times such as prehistoric cave paintings and on the rock walls. In Indonesia, comic tradition has existed since antiquity and its existence can still be encountered now. Like the reliefs depicted on the temples. Pictures and writings made on pottery and pottery and pic- tures on тапи script on palm leaves. On the palm lontar, there is a $100 \%$ text story. There is a $100 \%$ image (no text) and there is a combination of images with text like lontar prasi. So it's like a comic that we know today ${ }^{1}$

The existence of traditional comic-like artwork can still be found and its activities in several places are still ongoing in Bali. Like "Kamasan Puppet Painting". The word "Kamasan" itself refers to the name of the village itself and also refers to the history that the art has once reached the "glory" era; "Golden" in the reign of Dalem Watu Renggong king in Gelgel.

This traditional Balinese puppet painting in antiquity spread throughout Bali with activities centers in Puri or the kingdoms of Bali. Puppet kamasan painting is one form of art as well as a medium of religious moral teaching.

The generation that grew up in this era of media is faced with various forms. But behind from what is described slowly fades and loses meaning. This condition occurs in the younger generation today they see just the puppet just visually no longer see the value and philosophy behind it. It also causes the image to become duller.

Puppet kamasan has a rule of "pakem" or pattern used by the "sangging" or artist in making the painting, which is delivered orally from generation to generation gradually occur distortion and loss of true rules. Compared to the known "comic" knowledge now, we can compare the extent to which puppet kamasan paintings can be categorized as comics in the terminology of modern knowledge, what elements it possesses. So this is very important described to be known to the younger generation and society in general. 
Besides, to know the values and philosophy in the character of the puppet that the terms will be symbolic, both in history and the process of its formation. Likewise To be used as a development of modern comics that have local color or Indonesian identity.

\section{The Theoretical Background}

The traditional art of puppet kamasan painting in a review of the comics of today has a similar way of speaking, it's just different media and engineering workmanship. The similarity of the way in the comic as expressed by McCloud (2002: 9) provides the notion of comics as "images and symbols in a certain order to convey information and or achieve aesthetic responses from" readers ". Images in comics are sequential static images that relate to each other that form a story ${ }^{2}$.

Basically, comics have sequences. The sequence in the picture is shown in the panels that can reveal the scene, time, moment, atmosphere, emotion and so on. In the comics "sequence" is described explicitly through the panels that describe the sequence of stories. Unlike the case of puppet kamasan paintings, the sequence or panel is not depicted as a kind of dividing line but more disguised made with ornament or motif "karangan" "baturan" and " karang tepel".

Kamasan puppet paintings can also be categorized into comics because they have strip comics as revealed by Bonneff (in Maharsi, 2011: 15) the comic form is divided into two categories: comic strips and comics. Comic strips refer to comics consisting of only a few panels and usually appear in newspapers or magazines. Comic strips are continuous in every publication or only once aired..$^{\mathbf{3}}$ Kamasan puppet paintings generally contain episodes depicted in three panels or just one panel that tells a scene without dividing to the panel.

The division of panels in kamasan puppet paintings is commonly divided into three panels based on the Balinese concept of space called "Tri Loka" and the social conception of "Buana Alit and Buana Agung" applied to the making of the painting as a reference. The painting or wandering of kamasan puppet paintings still refers to the classical puppets or shadow puppet "purwa" often performed in the community. Historically, Bali has inherited the forms of puppet in the temple Javanese eastern.

\section{The Research Method}

As a traditional Balinese art work, related to visual, this research uses qualitative descriptive method with the intention to study painting in physical form and narration behind it. Similarly, the Balinese view of life. This research does not present data but presents report data, images obtained from research.To further focus this research using visual analysis that has a sequence starting from the process of observation. Observation requires seriousness to look at with a systematic consideration because to know a visual work such as know someone, the longer and more often see a work that increasingly recognizes the visual work. ${ }^{4}$ (Soewardikoen, 2013: 39). It is further explained to analyze the visuals to systematically pass through the following stages: First, the de- scription stage breaks down the visual form one by one from what appears to be an objective assessment, without opinions or interpretations. Second is the analysis phase, the third stage is the stage of the interpretation stage and the last is the assessment stage is the synthesis of inter-case analysis that occurs in the work of art.

\section{The Result and Discussion}

Kamasan Village is a center of Purwa puppet painting in Bali, located in Klungkung district can be reached in less than an hour east of Denpasar city. Kamasan village became the art village and tourist destination of Bali area because there are many wayang painting studios which were pioneered by the late maestro Nyoman Mandra, around the 80's. He gathered young men to be nurtured and wrought in order to keep preserving the kamasan puppet paintings and the values that existed in the artwork. From there a lot of puppets painters arise and have their own studio as a studio and training to make puppet painting.

At the time of Balinese classic Hindu, Kamasan village has a history as a center for the development of puppet art during the reign of Dalem kings namely kings kingdom of Sri Krishna Kepakisan from the Majapahit Kingdom. During the dynasty held the power of government in Bali, the art of Bali experienced a heyday during the reign of Dalem Waturenggong in Gelgel in the 15th century AD around the year 1386-1460. In the inscription, bebetin told the king get a prize gedok shadow puppet from the king of Majapahit from there to develop the of puppets ${ }^{5}$ Kamasan village became a Purwa puppet painting area under the guidance of the Castle of the Kingdom next known as Kamasan puppet painting. Subsequent developments of this art only survive in the palaces of the kingdom is not spread in the community. So the kings who are very concerned about this art can survive as did the king of Klunkung (God the Great) around the 17th century. Expanding the function of Painting puppets not only as a complementary ceremony and ornament of the sacred building but as a medium of spiritual awareness.

Characteristics of kamasan puppets depiction take the face of three-quarters of the part, it will look the difference between shadow puppets with puppet painting. The rules of the make of the figures and the place of the gods refer to the composition of Hira gis namely: First line below is where the punakawan, and ordinary people. The second's rows of the middle or the other side are the gigantic parts or the gandarwa. The three top rows of the gods. Each of nature has a characteristic of nature, namely: Swah loka, is the Utama plateau which is located above for the gods, Bhuah loka is a human residence, Bhur loka is Nista where other low creatures. 6

How to draw typology of wayang characters have similarities with mask typology. Typologies include "manis" and "bagus", "keras"types, and "aeng" types. Type "manis" or "bagus" type like god figure, knight, and goddess. Type "keras" as the figure of Bima, Anoman, type "aeng" like giant and gandarwa figure. The composition of painting a solid or full tendency very rarely leaves empty space. A play or story in a puppet is a fragment of a story that can be per- 
formed in one stage. For example, Purwa puppet plays in several episodes. Take the story of the mahabratha divided into 18 episodes commonly called Parwa. Ramayana is divided into 7 episodes called Kanda.

According to B.M Goslings, the current Bali puppets is a puppet that is older or more ancient than Javanese puppets. The reason is that the relief found in Jago temple in Tumpang location was built in the 13th century similar to the form of puppet found in Bali. While in the ancient wake-ups found in Java is not found reliefs that are motif as Javanese shadow puppet nowadays. ${ }^{7}$

Art of puppet in Bali in the development besides as shadow puppets, "wayang wong", developed as a work of art both sculpture, relief, and painting. The oldest Purwa Puppet found in Bali in the form of bronze relief depicts Semara Ratih. Since the year 1071 AD relief is stored together with the Wungsu Son inscription. Another puppets proof is Bhatara Guru's painting depicted on the Bhatara Guru inscription 1204 AD. Currently stored in Kehen Bangli temple.

\section{Analysis Result}

The purwa puppet traditional painting made in Kamasan village still uses traditional techniques and media. Starting from the making of canvas, color and painting equipment. The color they produce from nature, the blue green color is produced from the leaves of taums, the yellow and brown color of the soil called "pere" while the black color is produced from the soot (mangsi), while the white color to produced from animal bones such as deer, cattle, and pigs. This dye is mixed with a kind of glue called "ancur". For appliances such as brushes, pens, made from bamboo preparations.

The depiction of a story or episode in the Kamasan puppet painting in general sangging or artist divides the canvas field to be three panels, there are also two an none. Each panel represents one story adapter, which is connected with another panel. Commonly portrayed stories such as Mahabratha, Ramayan, Tantri, Panji, Legends and Balinese folklore.

The division of panels for sequential scenes in kamasan puppet paintings is not like reading panels on comics generally. The sequence usually starts from the top left then right and continues downwards, and repeats on and on. In the kamasan puppet painting, the sequence of panels is read from bottom to middle and top last.

This sequence is also like we to read the puppet stories on temple reliefs and in Bali temples. The bottom part is told first, then the middle panel and so on up to the top. The division of these three panels is based on the concept of space in the belief of Balinese society called Tri Loka which means three realms consisting of: Bhur Loka is a living creature like an animal and supernatural creature of low level. Bhuah Loka is the middle nature of nature or human space and Shwah Loka is the upper realm where the gods are.

This spatial or panel division is often misunderstood that the depiction of puppet characters as in the definition of $T r i$ Loka. God's figures must be drawn on the top panel, human figures should be depicted in the middle and as the animal on the bottom. Surely not so panel based only on the order or in the relief called the layers. As an example, we see in one of the Kamasan puppet paintings taking the Mahabratha story in the "Pandawa Swarga" story.

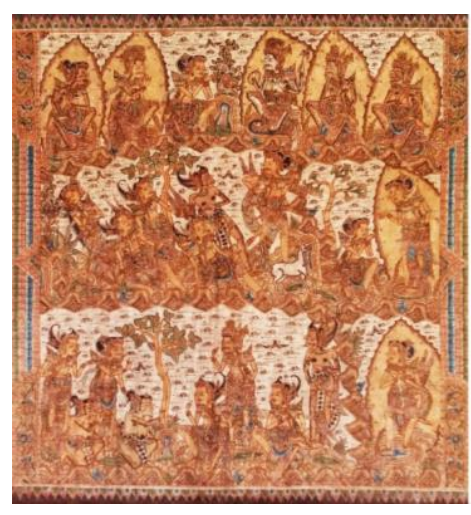

Figure1. Mahabratha "Pandawa Swarga" Sumber : Lukisan milik Pura Wira Satya Bdg

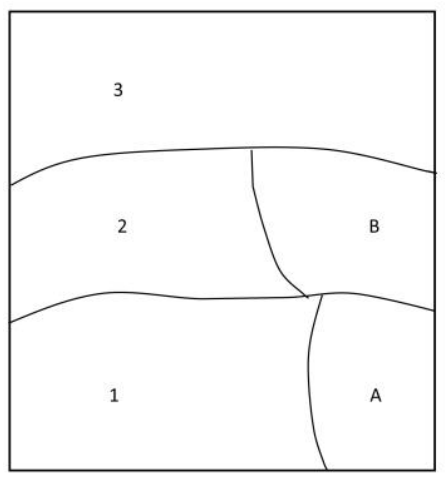

Figure2. Cara membaca urutan cerita "Pandawa Swarga"

The canvas is divided into three as illustrated in Figure 1: see the sequence of panels starting in numbers 1,2 , and 3 . In the 3-panel division, there are sometimes also added sub panels that can describe other dimensions or other times. Panel 1 tells that the Pandawas are gathering, discussing going to heaven, in another realm their discussion is heard by Bhatara Dharma (sub panel A). Panel 2, tells the journey to the peak of Mahameru (swarga) in the journey one by one Pandawa fall from the Dewi Kunti, Nakula-Sahadewa, Arjuna then Bima and the only surviving is Yudhisthira and a Dog. This dog is the incarnation of Bhatara Dharma (sub panel B). Panel 3, Yudistira's success reached Swarga and was welcomed by the Gods. In explaining something else sangging can usually add new panels to make the story more understandable. The panel can explain other dimensions, time, and story fragments to keep the message intact.

The distribution of panels in the shape of kamasan puppet paintings did not appear explicitly. The borderes panels are made with ornaments or stone motifs commonly called "karang batu". Sometimes the ornament of baturan in unified with " karang tapel " baturan means "stone" as a symbol of land or foothold.

Tri loka also explains the placement of figures in the social strata governing the space or position of the puppet characters in a panel, the character of the punakawan should be 
described lower than the knight or king, so also the position of the gods should be described higher than the human.

The way of visual speech, like kamasan puppet paintings, has similarities with other traditional painting traditions in Bali as it is done in Ubud area, placing that as far in the field above. The farther the object to be revealed the higher the object is placed in the canvas field. The bottom is told first and then upwards. Balinese painting is not familiar with a Western perspective.

\section{Conclusions}

Visual literacy has long been done both from prehistoric times until now, every era has its own way of disclosure in accordance with the values of society. Society now not familiar with the visual grip of puppets and the narrative behind the form and character. Moreover, understand the story line and the values of his philosophy. Their ignorance in reading the plot or sequence described will add to the blur of messages conveyed.

Storytelling through kamasan puppet have similarities with comic media. In the kamasan wayang paintings sometimes images are also given writing like in the comics now. The panel per panel description for story sequences starts from bottom to top. The division of the panel does not have to be three parts there are more Our understanding of the traditional arts will open our eyes that the arts inherited by our ancestors have high values that can be used as capital in anticipating the progress of time.even some who do not use.

\section{ACKNOWLEDGEMENTS}

The authors would like to thank those who have helped in this study: Research Institute of Community Service Telkom University for the grant funds; the research team, Yanuar Rahman, Made Rahma Bhawana Suta; and informant that supported the data completion.

\section{REFERENCES}

[1] Tabrani, Primadi. 2012. Bahasa Rupa. Cetakan ke 3 Kelir. Bandung.

[2] McCloud, Scott. 2001. Understanding Comic ( memahami komik) KPG. Jakarta.

[3] Maharsi, Indira.2011. Komik Dunia Kreatif Tanpa Batas.Kata Buku. Yogyakarta.

[4] Soewardikun, Widiatmoko. 2013. Metodologi Penelitian Visual, Dari Seminar ke Tugas Akhir, CV Dinamika Komunika, Bandung.

[5] Bandem, I Made, dan Rembang, Nyoman. 1985 Perkembangan Topeng Bali Sebagai Seni Pertunjukan, Proyek Penggalian Pembinaan Seni Klasik dan Tradisional dan Kesenian Baru, Pemda Tk. I Bali.
[6] Nilotoma, Sangayu Ketut Laksmi. 2013. Nilai Estetik Bale Kertha Gosa di Puri Semarapura Klungkung, Desertasi.

[7] Nilotoma, Sangayu Ketut Laksmi. 2013. Nilai Estetik Bale Kertha Gosa di Puri Semarapura Klungkung, Desertasi 